\title{
THE BRAZILIAN JUDICIARY AS AN ORGAN OF POLITICAL CONTROL
}

Ada Pellegrini Grinover

Full Professor at the Law College at University of São Paulo.

Grasielly de Oliveira Spínola

Universidade de Itaúna, Brazil.

\begin{abstract}
The fruition of fundamental rights like healthcare, education, worthy housing and work is directly related to the creation and implantation of universal and egalitarian public policies by the Congress and the Public Administration. In the cases where the existing public policies are shown to be insufficient, inadequate or do not achieve the fundamental goals of the Federative Republic of Brazil, it arises the need of the action of the jurisdictional function to control the constitutionality over these public policies. In Brazil, this control is made both by direct way, by means of its own constitutional actions, and by diffuse way, by means of collective actions interposed in first instances courts. In this context, the enforcement of the liberal theories like Montesquieu's Separation of Powers and the Intangibility of the Discretionary Activities reveal themselves incoherent with the Democratic Rule-of-the-Law State. In another way, the jurisdictional action is limited by the Reasonableness, by the Possible Reserve and by the Existential Minimum, and can also find some obstacles in the individual actions that end up influencing the public policies. Therefore, there is a great effort to colectivizing individual actions by Brazilian schoolars. Another problem is the difficulty of Judical Power in using the adequate procedural class action. It will be analyzed one specific decisions made by the Court of Justice of the State of São Paulo about the jurisdictional control of public policies related to the autistic people, with a goal to point out a direction to the improvement of the jurisdictional tutelage in terms of effectiveness and adequacy.
\end{abstract}

Keywords: Public Policies - Jurisdictional control - effectiviness and adequacy. 


\section{I - INTRODUCTION}

\section{Fundamental social rights, public policies and jurisdictional control}

The Brazilian Constitution, as well as the corresponding obligation of the government to provide the citizens with services that they are entitled to - which, in accordance with the same Constitution, are to be immediately effective - involve the necessity of positive benefits to be given by the government, and, hence, are called fundamental rights of having services provided. The fruition of rights, such as health, education, housing, work, a clean environment will, then, depend on the governmental organization that shall rule and implement the public policies (of an equalitarian and universal nature) through both the function of the legislative branch (lawmaking), and the administrative function (steps for implementation). However, the political powers (and mainly the Administration) often stand by. They lay inert or evolve inadequate public policies that do not meet the constitutional provisions (article 6 of the Brazilian Constitution) nor the fundamental goals of the Federative Republic of Brazil (article 3 of the Brazilian Constitution). At this moment, always a posteriori, the jurisdictional function may be brought into action, as long as it is invoked, and carry out the constitutionality control over the public policy, even taking actions to implement or correct it.

For this purpose, the Brazilian legal system establishes specific constitutional procedural instruments, such as the direct action of unconstitutionality, declaratory action of unconstitutionality by omission, action of obedience to the fundamental precept and the mandatory injunction. However, as it happens in Brazil, the constitutionality control is not carried out in a direct way only, but also in a diffuse way ${ }^{1}$ So, the first instance courts of law are responsible for carrying out the constitutionality control over the public policies, implementing or correcting them, making use of collective actions, which are of an equalitarian and universal nature, just like the public policies, leading to the res judicata erga omnes.

That point of view was rejected at first, but now it is totally accepted by the jurisprudence and by most of the Brazilian scholars. There were two opposing theories: the theory of separation of powers and the principle of intangibility of the discretionary activities of the Administration.

But the strict application of the theory of separation of powers,

$1 \mathrm{It}$ is worth having in mind that in Brazil the contentious administrative proceedings do not exist, and it is up to the judiciary branch to acknowledge and judge all the disputes even if the state is one of the parties. 
created by Montesquieu, modeled by the principles of the liberal state, and according to which the judge's role was only to be the mouth of the law, cannot be accepted by the social state any longer, and much less by the democratic rule-of-the-law state, to which the state is one single unit, and so is its sovereignty. The so-called powers of government just represent the state functions, whose exercise is originally awarded by the Constitution, but whose performance may be submitted to the control of the judiciary branch, the last guardian of the Constitution ${ }^{2}$

The principle of intangibility of the discretionary activities of the Administration, according to which the judiciary branch could only review the legality of the administrative act, but not its grounds (that is, its opportunity or convenience), has also been worn away along the time due to the broadening of the legality concept towards the administrative activity. It ended up embracing not only the legal formal written texts, but also matters regarding the finality, the cause and the reasoning of the administrative act, as well as its real aim. Consequently, the concept of power misuse has arisen and allowed the intervention of the judiciary branch. In Brazil, the last attempt, which definitely put an end to the idea of intangibility of the discretionary act, was set forth by the 1988 Constitution, since it allows a constitutional popular action to be filed against an administrative act that may be, in some way, harmful to the administrative morality. Morality shall not be mixed up with legality: the act may be both legal and immoral.

Following the same principles, the possibility of jurisdictional control of the public policies has been adopted by several countries. India, South Africa, Argentina and Colombia, among others, have many lawsuits to submit the public policies to the jurisdictional control (in the courts of law, although more often in the Supreme or Constitutional Courts). It is not a coincidence that the necessity of control is more urgent in emerging countries, where the legislative and the executive branches often lay idle and the fundamental social rights are less respected.

\section{Limits to the jurisdictional performance over the control of public policies}

Although the jurisdictional control of the public policies has received the approval of the jurisprudence as well as of most of the Brazilian scholars, the Brazilian Supreme Federal Court wanted to

2 Since the middle of the $19^{\text {th }}$. century, Justice Marshall, in the famous case Marbury vs. Madison, Justice Marshall established in the United States the principle that awards the constitutionality control to the judiciary branch, and may even undermine the law that offends the Constitution. And the Brazilian republican Constitution has adopted that principle, which is in force until today.// 
make clear that the control has to be seen as being exceptional and exist within certain limits ${ }^{3}$

The first limit is the reasonableness of the intention to implement or to change some specific public policy and the unreasonable idleness or choice of the administration. ${ }^{4}$. Just in this case the judiciary branch is allowed to interfere, substituting its choice by the one of the administrator.

The second limit is the contingency reserve fund (reserva do possivel), a concept originated from the German constitutional jurisprudence: if a public policy is to be implemented or even modified, it must have enough funds in the state's budget. ${ }^{5}$

Finally, the last limit, also originated from the German constitutional jurisprudence, is the existential minimum, which corresponds to the hard core of the fundamental rights, and without them the human being lacks dignity ${ }^{6}$.

The existential minimum is also considered a limit to the limits, as its existence dismisses the obligation of the contingency reserve fund, according to another decision by the Brazilian Supreme Federal Court.

\section{The public policies and the individual actions}

It has already been said thatthe collective actions are the proper procedural way to the jurisdictional control of the public policies. Due to their necessary equalitarian and universal nature, they are the only ones that may give an equalitarian and universal jurisdictional answer. However, the access to justice, guaranteed in the article 5, item XXXV of the Constitution, rules not only the collective protection, but also the individual protection of the subjective rights.

It is inevitable, therefore, that together with the collective actions, whose specific aim is to implement or correct public policies, several individual suits proliferate. They intend to seek after compensation for

3 The leading vote of the Supreme Court in this issue was from Justice Celso de Mello, in the ADPF, number 54 of 2012.

4 It is worth noticing that according to the terminology of the Brazilian Supreme Federal Court, the principle of reasonableness mixes up with the principle of proportionality. Although the doctrine points out some differences between the two principles, it is possible to ascertain that the reasonableness is the subjective sub-criteria of the proportionality, and, in a concrete situation, the judge is in charge of choosing the value that seems to be worthwhile protecting, according to the criteria that sensibly show the common sense.

5 However, it is necessary more than the allegation of inexistence of funds. It has to be proved. The impossibility to reallocate the budget has to be proved, too. And the judge may sentence the executive and the legislative branches to make a specific budget forecast for the following year./ 6 It has been argued the nature of the existential minimum by the scholars: absolute or relative, static or dynamic, external or internal. For us, each fundamental right has its hard core, to be checked in the concrete situation, according to the circumstances. 
personal subjective rights, and, indirectly, end up influencing the public policies.

The influence of the individual actions over the public policies is most of the times negative, as the judge's order to grant the individual claims falls over the amount of money to be shared among all, and, hence, it becomes significantly reduced, as already shown by the statistics. Sometimes, however, the repetition of individual actions with the same object may induce the administration to change the public policies, as it has already happened with the cocktail anti-aids and, more recently, with a more modern, effective, with few side effects medicine against diabetes, which was not in the list of medications of the Unique Health Care System (Sistema Único de Saúde).

\section{The critics of the judicial activism and the judge's co-participation in the political arena}

The judge's co-participation in the political arena, with the possibility of intervention in the legislative and administrative activities, mainly towards the public policies, is not exempt from critics directed to the so-called judicial activism.

The most important critics refer both to the lack of the judge's democratic legitimacy, as he is not elected, as well as to the lack of the judge's qualification, as he would not be as prepared as the administrator to make political choices.

It is exactly the fact that the judge is not elected that makes him much more immune against the political pressure that is exercised over the majority powers, and end up influencing his choices. In a majority system, like ours, the minorities' voice is suffocated and can only be heard through the judiciary branch. It is clear that the judge is obliged to hear complaints and direct them using a dialectic process, and to assume personal responsibilities because of his decisions, as well as to justify them based on reasons that are socially acceptable. The content of the jurisdictional function is essentially public, and, besides solving disputes, gives meaning and concrete expression to the public values that define a society and give it identity and coherence. On the other hand, the democratic legitimacy of the judiciary branch comes either from the polls or, more exactly, from the principles and guarantees that rule the exercise of the jurisdictional function: the impartiality, the adversarial system, the ample defense, the reasoning for the decisions, the publicity, the internal control and the political control.

Concerning the alleged judge's lack of qualification because he is not acquainted with technical matters, such as the budget or the administration plan regarding the public policies of a specific area and its progressive implementation, whose aim is to have coherent, balanced, 
fair and achievable decisions, we shall recognize that nowadays, mainly in Brazil, the judge is not duly informed, is isolated, does not have specialized assistance, is far from the administration or even from other judges or appellate courts that face similar matters.

That is the reason why the next item will approach the institutionalization of a new action, more adequate to solve the so-called conflicts of public interest, as being a suitable technique to overcome the above mentioned problems.

\section{The conflicts of public interest and its adequate jurisdictional protection. Characteristics of a new action}

The conflicts of public interest or strategic are the ones designed to implement the fundamental collective rights, which means, to discuss the performance of important institutions or public services, such as the school systems, the prison systems, institutions or organizations that are responsible for protecting the public health, access to transportation, housing, sewage treatment, and urban mobility. That was the origin of the disputes of public interest that have happened since the decade of the ' $50 \mathrm{~s}$, in the last century, in the North-American legal system ${ }^{7}$.

This way, the recognition of the existence of an important category of public right disputes has been asserting itself, and should be differenced from both the procedural protection aimed at solving private disputes, as well as from most of the collective protection, because at this moment the dialogue that prevails in the action has an institutional nature, involving other state "powers". The decision is not about past events anymore on which the law should be applied, but it will be reflected in the future in a prospective dimension. The judge's order must not say "pay" or "do" anymore, but it has to be a mere indication of the steps to be taken in order to obtain the result intended by the decision.

And that decision must be a result of the dialogue between the parties and mainly among the powers of the government, opening the adversarial system also by having public hearings and the intervention of third parties like the amicus curiae. The judge's knowledge must be widened with the help of specialized assistance and with the information provided by the administration itself, so that if there is not any settlement, the judge can be informed about the effects of his decision, which has to be fair, balanced and enforceable. The enforcement of the decision, in turn, must be made flexible, with the participation of the administration, by having plans approved by the judge, who must follow up its

7 Widely known is the landmark judgment "Brown vs. Board Education of Topeka", which was judged by the Warren Court together with other precedents that permitted the development of the doctrine. Mauro Cappelletti was the great propagator of those ideas among us in 1976.// 
enforcement, with the help of an independent third party from public or private organs, who will be responsible for its enforcement, always in close communication with the judge and on his command.

This new action, which requires great judicial activism, the widening of the judge's powers, as well as the dialogue method, including the dialogue among the powers of the government, greater publicity, participation and transfer, does not exist yet. However, the jurisprudence of several countries has been able to create it, modifying the classic procedural methods.

A landmark judgment and an interesting example to be followed is the case of Beatriz Mendoza, which was filed before the Supreme Court of Argentina, and whose plaintiffs were some groups of individuals who suffered damages, several environmental associations and the People's Defender. The defendants were the national government, the Buenos Aires Province and the autonomous city of Buenos Aires, as well as a group of 44 companies that supposedly poured polluting chemicals into the river basin. The court freely exercised its order power, used the principle of preclusion flexibly, and required the states the peremptory presentation of an integrated and complete plan based on the principle of progressivism, so that objectives could be gradually obtained, and according to a chronogram. In July of 2008 the final decision definitely put an end to the matter, pointing out that the effects of the decision will have reflections in the future. It also determined general criteria to the decision enforcement, however respecting the limits of the discretionary powers of the administration. Concerning its enforcement, the decision set forth the citizen participation to monitor the accomplishment of both the sanitation plan, as well of the action plan that was established. The People's Defender was required to monitor compliance with the judgment, by forming a collegiate body comprised by non-governmental organizations involved in the litigation. The enforcement of the decision is still in progress, in a gradual way, and following the chronogram.

In Brazil, the appellate courts have not been so careful, and after the judgment, which is stiff and fixed, there has been some difficulty to enforce the decision. The dialogue with the administration has turned out to be essential. More recently, in a collective action filed by the Prosecution, whose aim was to request the necessary availability of thousands of places in day-care centers, there were at least public hearings and the enforcement was based on the Plan of Goals, which is progressive, and was presented by the mayor of São Paulo when he was a candidate.

However, the best solution would be to rule, through the legislative activity, a new action to discipline the jurisdictional control of public policies, with the above mentioned characteristics, which would balance the three powers of the government, and the commitment 
to seek consensual solutions, and even to make the judge more secure to issue decisions and solve litigations not based on the past anymore, but looking at the future ${ }^{8}$

\section{II - AN EMBLEMATIC CASE OF FAILURE IN THE INADEQUACY OF DECISION ON PUBLIC POLICY}

\section{About Autism: Diagnosis, Symptoms and Treatments}

This is a global dysfunction of development that typically appears during the first three years of life and affects the ability of an individual'scommunication, socialization (building relationships) and behavior(responding appropriately to the environment). This disease affects about 20 out of every 10,000 births and it is four times more common in males than in females.

Some autistic children may exhibit intelligence and clear speech, others, however, have serious limitations in language development, interaction, and may appear distant or introspective and locked in rigid and limited patterns of behavior.

One of the most common myths about autism is that autistic people live in their own world, only interacting with the environment they have created, but this is a fallacy. If, for example, an autistic child is alone watching other children playing, it is not due to the fact that the child is necessarily uninterested in these games or because they live in their own world. Most often this occurs because this child presents real difficulty initiating, maintaining and properly ending a conversation or joke, which is actually regarded as difficulty in interaction. ${ }^{9}$

Autistic spectrum is another term denominated to the various forms of manifestation of autism, which indicates a range of possible symptom. According to clinical analysis, it can be split into 3 groups:

1) complete absence of any interpersonal contact, inability to learn how to speak, incidence of stereotyped and repetitive movements, mental retardation;

2) the carrier is self-focused, does not establish eye

8 A Bill on this matter has been prepared by Cebepej - Centro Brasileiro de Pesquisas e Estudos Judiciais (Brazilian Center for Researches and Judicial Studies), founded by Kazuo Watanabe and currently presided by Ada Pellegrini Grinover. It was submitted to debates and will soon be presented to the National Congress

9 GAUDERER, E. Christian. Autismo e outros atrasos do desenvolvimento: guia prático para pais e profissionais. Rio de Janeiro: Revinter; 1997. p 3. 
contact neither with people nor the environment; can speak, but does not use speech as a communication tool (is able tore peat complete sentences but out of context) and has impaired understanding;

3) mastery of language, normal intelligence or even above average, less difficulty with social interaction that allows the carriers to live an almost normal life.

In adolescence and adulthood, the manifestation of autistic symptoms depends on how people were able to learn the rules of social behavior and develop that behavior which favors adaptation and selfsufficiency in childhood.

Each autistic child should then be diagnosed and begin treatment as soon as possible, and this treatment should be directed to the needs of each individual, according to the autistic spectrum, both in health institutions, as well as the school environment attended by the child.

It is important to emphasize that therapy requires a multi and interdisciplinary team composed of medical care of pediatricians and psychiatrists and non-medical treatments, with psychologists, speech therapists, pedagogues, occupational therapists, and educators prepared to deal with special needs. All these procedures are able to provide a progressive evolution of the prognosis and social inclusion of the autistic child.

\section{The Jurisdictional Control of Public Policy Related to Autism in São Paulo}

In 2000, triggered by a complaint made by the father of an autistic child, the Public Ministry of the State of São Paulo initiated a Civil Inquiry to verify whether the State provided specific treatment and education to attend the needs of people with autism.

Following an authorized investigation, it was confirmed that the State only made a common psychiatric treatment for autistic patients available and not a specialized treatment to meet the specific needs.

The State Prosecution Department tried to sign an agreement with the Government, but the State of São Paulo showed no interest in including specialized treatment as part of the Unified Health System, nor provide institutions specialized in the education and training of people affected by this disease.

Thus, the Public Prosecution Department filed a Class Action (called in Brazil Public Civil Action) ${ }^{10}$ with a request for preliminary injunction against the Government of the State of São Paulo, requesting full compensation from the defendant for the treatment, care and 
education of autistic patients in specialized treatment institutions.

This class action was heard in the court of first instance to order the Government of São Paulo, to bear the full value of the treatment, care and education of autistic patients in specialized private institutions for all residents in the state, as long as it has no free specialized treatment units for autistic patients, as specified in the passage of the operative part of the law suit below:

I JUDGE FOUNDED the Civil Action brought by the Public Prosecutor of São Paulo against the Government of the State of São Paulo, based on article 269, paragraph I, of the Code of Civil Procedure, to order it, so that if the want, own and provide free specialized units, never existing for the treatment of "common" mental patients, for health care, education and healthcare to autistics, specializing in full or part-time for all residents of the State of São Paulo:

I - Coping with the full costs of treatment (specialized hospitalization or full-time regime or not), counseling, education and health specific, fund specialized treatment for non-state entity suitable for the care and assistance to residents in autistic State of Sao Paulo;

II - By application of the legal representatives or guardians, accompanied by a medical certificate attesting to the situation of autistic addressed to the Hon. Secretary of Health and filed with the office of the Secretary of State for Health or sent by letter with acknowledgment of receipt, the State will have a period of thirty (30) days from the date of filing or the receipt of the registered letter, as the case, to provide, at its expense, appropriate institution for the treatment of autistic applicant;

III - The institution nominated for the autistic requester by the State should be as close as possible to their home and their families, with, however, the body of the application may include the institution of preference or responsible representatives of the autistic, while the State support infeasibility of the statement, if applicable, and elect another 
appropriate entity;

$I V$ - The system of treatment and care in full-time or part-time period, always specialized, should be specified in the medic prescription certificate itself, and the State shall provide entities with such characteristics;

$V$ - After the state to provide the indication of the institution, the State shall notify the person responsible for the autistic providing the necessary data for the start the treatment. For cases of noncompliance with obligations to make the items I to $V$, fixed daily fine of \$50,000.00 (fifty thousand reais), for the State Fund Interests metaindividual injured (Article 13 of Federal Law No. 7347/85), and the reverse maximum period of 30 (thirty) days from the date of intimation of this decision to provide, permanently, such care to autistic children.

The Government of the State of São Paulo appealed against that decision, alleging interference by the judiciary in the executive branch, which was dismissed by the Third Public Law Chamber of the Court of Justice of São Paulo:

PUBLIC CIVIL ACTION - Providing specialized treatment for autistic - Alleged lack of interest and procedural illegitimacy of prosecutors - not recognized - Article 5 CF - Norma constitutional for protection on public health - Alleged interference by the judiciary in the executive branch - not recognized. ex - Judicial Control on discretionary activity-Guarantee of the right to public health Implementation of a daily fine for noncompliance - Aim to compel the administrator to implement public policies - Resources not provided. ${ }^{10}$

The Court of São Paulo upheld the decision at first instance, considering that the State Government can not state administrative discretion to maintain legal budget forecast (Theory of Possible Reserve). If this were the case, the exercise of collective, diffuse, individual rights or public interest would always be subjected to administrative discretion

10 TJ/SP Apelação Cível nº 278.801.5/8-00 
and the willingness of the administrator to insert the necessary funds in the budget.

When analyzing the provisions of the sentence that was issued on December 28, 2001, it is acknowledged that judicial control of public policy related to autism was conducted in order to ensure compliance with the decision because the magistrate not only focused on the state to supply treatment, but one that is appropriate and in specialized institution close to the patient's home in order to facilitate their access.

Nevertheless, while displaying many specific and too detailed commands, it ended up complicating and hindering their compliance.

The first difficulty is related to the type of compliance to be made, which can only be individual. This means that every time an autistic person has to seek rights guaranteed in the sentence, they should seek the health department, perform certain procedures, indicate the institution of their choice and wait for thirty days to have the management response with the location and start date for the treatment.

If the Health Department remains inert or partially fails to comply with an order of the sentence, the representative of the autistic patient should initiate a Single Sentence Execution, with reasons which substantiates their claims.

Taking into account the number of inhabitants of the state of São Paulo - location of the decision in question - and the number of autism diagnosis, it is hard to measure the infeasibility of the judiciary to appreciate, each case and therefore the delay in compliance with court order.

As soon as the decision became final, the individual executions were initiated by autistic individuals, through their legal representatives, and after action together with the secretary of health and education, the judge ordered the refund of amounts paid to private institutions by the defendant through the legal deposit system.

However, eight years after the order of the judge and when thousands of acknowledged individual executions had piled up under one jurisdiction, the Assistant Judge, who had just taken over the 6th Court of Exchequer Capital, saw fit to abolish individual executions based on art. 462 of CPC (supervening grace in of actions taken in the main proceedings) while at the same time, ordered the State to take steps to register and provide appropriate treatment in autistic patients in administrative form.

Moreover, the judge decided that new acknowledgements could not be prosecuted because the defendants should endeavor directly before the State Department of Health - in negative adjudication. Further determined that the Public Prosecutor of São Paulo, after gathering the responsible representatives of the autistic patients through the press and television, propose a unique and ultimate execution of sentence. 
This decision brought real procedural turmoil, having even caused suspicion against the judge for "lack of sensitivity to the autism cause" and although the charges were dismissed as unfounded, the judge was removed from office.

This act of judgment in practice annulled the effects of the earlier decision given in the process of knowledge (decision was confirmed by TJSP and non-appealable), a clear affront to the Due Process and Material res judicata. Furthermore this act left the autistic people of São Paulo in the same helpless condition they were before the filing of the Civil Action in 2000.

The São Paulo Public Prosecution filed a bill against the decision with a request for a suspension effect, claiming offense to art. 125 and 471 of the Procedural Civil Code, Consumer's Defence Code 81, 16 Public Civil Action Law and art.5, XXXV of the Constitution.

The Court of São Paulo demonstrating consistency with previous decision granted the injunction to suspend the effectiveness of any act aggravated and determined the following judgment statement:

COLLECTIVE ENFORCEMENT
IMPLEMENTATION.PRINCIPLE DEVICE.
ASSIGNMENTS OF JUDGMENT. 1. Judicial
executive title contains provision of a collective
nature, being unfeasible of satisfaction, allows
the filing of executions individuais2. The purpose
of the civil action, the court consolidated the
command enforceable prevent it is to be autistic
taste of fruitless discussion with the Secretary of
State as to the technical capacity of the institution
elected to provide medical services when the state
does not provide the effective means for providing
a clear demonstration affront to the dignity of the
human person and Justice. 3. Aggravated the act
nullifies the judgment of this Court and do things
return to preceding the filing of the civil action state.
grievance provided ${ }^{I 1}$

As expected, aware of the constitutional and procedural effect, the TJSP annulled the effects of interlocutory decision rendered by the judge of the 6th Court of Exchequer of São Paulo upholding the interlocutory appeal brought up by the São Paulo Public Prosecutor in 09 April 2006, guaranteeing the rights of the autistic patients to receive proper and free treatment provided by the state and also emphasized the

11 Agravo de Instrumento 767.934-5/4-00 
unfeasibility of leaving them at the mercy of the State Secretariat for the faithful compliance of the judgment ruling.

\subsection{The inefficiencies of the hudicial decision due to the implementation based on the wrong class action}

Despite the Justice Court of São Paulo having acted correctly when revoking the effects of the decision, which was clearly contrary to many legal and constitutional provisions, the agreement did not solve the problem of trial inefficiency. The individual compliances continued to overcrowd the courts and the jurisdictional still had to wait a long time to receive judicial protection and receive the reimbursement to which they were entitled.

Accordingly, this whole problem could be solved if the Public Prosecution had sought the tutelage of Collective Rights instead of the Homogeneous Individual Rights, as can be seen in the following.

\subsection{Diffused, Collective and Homogeneous Individual Rights}

Article 81, unique paragraph, clause I of the Code of Consumer Protection - which applies by express legal provision protection of collective rights of any kind - states that diffuse interests or rights are "trans-individual, indivisible by nature, and held indeterminate people who are linked by factual circumstances."

Now the collective rights set forth below, in section II of the same statute, are "indivisible by nature of trans-individual that holds group, category or class of persons connected with each other or with the other party by a legally based relationship."

Gregório Assagra de Almeida direct us on the differences between the two ${ }^{12}$ :

In the rights or diffuse interests there is no legal basis prior relationship, because people are connected by mere factual circumstances, whereas the collective in the strict sense it is important to have legal basis prior relationship between the members of the category, class or group people or between such persons and the other party.

The individual homogeneous rights or interests are, by legal definition of art. 81, sole paragraph III, of the CDC, due to the common

12 ALMEIDA, Gregório Assagra. Direito Material Coletivo: Superação da Summa Divisio Direito Público e Direito Privado por uma nova Summa Divisio Constitucionalizada. Del Rey: Belo Horizonte, 2008. 
origin. They have to hold perfectly individualized persons, who may even be indeterminate, but are amenable to determination.

At first, it might be thought that the fact that all stakeholders are autistic, it would consequently provide a guardianship of homogeneous individual interests, but the law is clearly diffuse, as extracted from Kazuo Watanabe lessons, which differentiates the institutes.

The interests or 'diffuse' rights, its indivisible nature and the non-existent base of the legal obligation do not possibility, as already seen, the determination of holders. Of course, a more general level of legal phenomenon under analysis, it is always possible to find a bond that unites people, such as nationality. But the legal basis relationship that interests us, the setting of the concepts under study, is that which is derived from the interest tutoring, so that keeps most immediate interest and close relationship with the injury or threat of injury. ${ }^{13}$ (highlight)

It seems, therefore, that the common origin of all carriers of autism is not the existence of a legal base relationship, but a "de facto" relationship, which is, being carriers of the same disease. As we have seen, the holders of diffuse rights are indeterminate and indeterminable, united only by a circumstance of fact, for example, live in the same region, consume the same products and so on.

Therefore, in this case the relationship that binds all holders of the diffuse law is the fact that they are carriers of the same disease.

Yet the fact of being indeterminate subjects of diffuse rights, so are those with autism, because being a carrier of the disorder is not necessarily being diagnosed with the disease, especially in a state like Sao Paulo where many people live below the poverty line and have less access to health. Furthermore, as Kazuo Watanabe transcribed above, it might not be possible to define the subject of a diffuse law, to a lesser or greater degree in legal terms there will always be a bond between the holders, in this case, the disease.

\subsection{Importance of recognizing the rights and common interests in the case of autism, for efficiency judged}

As we have seen, the rights related to autism are clearly diffuse and so they should have been conceived and analyzed by the Public Prosecutor, when the proposal of the São Paulo Civil Action was put forward, in order to reach the desired effectiveness.

When the action tutoring homogeneous individual rights was mistakenly proposed by the parquet, it caused the fragmentation of interest and consequently forced their holders to individually pursue their compensation benefit, in which they should assemble extremely complicated proof of their specific conditions.

Moreover, the judiciary was overloaded with thousands of 
individual judicial executions and failed to ensure widespread access and treatment for all autistic children, since a large part of the population especially the poorest, was unaware of the lawsuit that guaranteed them the right to treatment.

On the other hand, if the Public Prosecution had filed a Civilian Public Action for protection of diffuse rights, requiring the condemnation of the State of São Paulo in its first compulsory duty, to first and foremost present a plan, which is gradual and progressive, capable of delivering appropriate educational and medical treatment to autistic patients in a multidisciplinary approach, stipulating terms and fines for noncompliance, certainly there would be a greater chance of effectiveness of the jurisdictional provision.

\section{III - CONCLUSIONS}

In Brazil, the judicial control of public policies is admitted, but is hasn't been applied appropriately and effectively.

The decisions of the State of São Paulo, related to autistic people showed genuine interest in the welfare of this group of people and outline guidelines for compliance.

The role of the Public Prosecutor of São Paulo was important to progress in protecting the rights of people with autism in that state, because he used the appropriate investigative procedures, produced evidence to support its claim, and he implemented the public policy in a proper way, which is the collective way, and incisively acted to put an end to the abuses of judgment execution.

However, the court decision meant to implement public policy has not achieved the desired effectiveness, since the interest has been conceived as a homogeneous individual, when in fact, it was diffuse interest. This misconception of the Public Prosecutor to judge the Civil Action São Paulo, which was not remedied by the decision of first instance or by Justice Court of São Paulo resulted in veritable landslide of individual executions, requiring complicated evidence which took a long time to be verified. The result was the ineffectiveness of trial.

If the rights of the autistic people had been treated as diffuse, and the sentence which implemented the public policy had widely condemned the state to a first compulsory obligation, ordering the State to submit a feasible project for gradual implementation service to meet the diverse needs of people with autism to be negotiated with the Public Prosecution and approved by the judge - who should also monitor compliance with the judgment, by persons or institutions interested in the judicial guidance - the decision would have full effect, benefitting all people with autism in the state, including the underprivileged people who are not aware of the judiciary decision. 


\section{IV - BIBLIOGRAPHY}

ALMEIDA, Gregório Assagra. Direito Material Coletivo: Superação da Summa Divisio Direito Público e Direito Privado por uma nova Summa Divisio Constitucionalizada. Del Rey: Belo Horizonte, 2008.

APPIO, Eduardo. Controle judicial das políticas públicas no Brasil. Curitiba: Juruá, 2008.

ARANTES, Rogério Bastos. Judiciário e Política no Brasil. São Paulo: Sumaré, 1997.

ARAUJO, Ana Luiza Gomes de. Controle Jurisdicional de Políticas Públicas. UFMG: Belo Horizonte, 2006.

BARROSO, Luiz Roberto. O direto constitucional e a efetivação de suas normas: limites e possibilidades na constituição brasileira. 5 ed. Rio de Janeiro: Renovar, 2001.

BERIZONCE, Roberto, Los conflitos de interes público, pp 3/32, disponível em www.direitoprocessual.org.br

CAPPELLETTI, Mauro, Vindicating the Public Interest through the Courts: A Comparativist's Contribution, 25 Buffalo L, Rev., 643, 1976.

CHAYES, A., The Role of the Judge in Public Law Litigation, 89 Harv. L. Rev, 1281, 1976.

COMPARATO, Fábio Konder. O Ministério Público na Defesa dos Direitos Econômicos, sociais e Culturais. In: GRAU, Eros Roberto et al (Coord.). Estudos de Direito Constitucional em homenagem a José Afonso da Silva. São Paulo: Malheiros, 2003.

FISS, O. The forms of Justice, 93 Harv. L. Rev. I, 1979.

GAUDERER, E. Christian. Autismo e outros atrasos do desenvolvimento: guia prático para pais e profissionais. Rio de Janeiro: Revinter; 1997.

GRINOVER. Ada Pellegrini. WATANABE Kazuo. (Coordenadores) $O$ controle Jurisdicional de Políticas Públicas, Rio de Janeiro: Forense, $2^{\mathrm{a}}$ Ed. 2011.

O Controle Jurisdicional de Políticas Públicas, in O Controle Jurisdicional de Políticas Públicas, coord. Ada Pellegrini Grinover e Kazuo Watanabe, Gen-Forense, 2a Ed, 2011.

Processo coletivo, in Teoria Geral do Processo, collaboration of CINTRA ANTONIO CARLOS ARAUJO and CÂNDIDO DINAMARCO, $30^{\circ}$ edição, São Paulo, Malheiros Editores, 2014.

GRINOVER, Ada Pellegrini. WATANABE. Kazuo. NERY JÚNIOR. Nelson. Código de Defesa do Consumidor comentado pelos autores do anteprojeto. $10^{\mathrm{a}}$ edição. Rio de Janeiro: Forense, 2011.

SARLET, Ingo Wolfgang; TIMM, Luciano Benetti (Org.). Direitos fundamentais, orçamento e reserva do possível. 2. ed. Porto Alegre: Livraria do Advogado, 2010.

SCHWARTZMAN, José Salomão. Autismo e outros transtornos do espectro autista. Revista Autismo, 2010. 
Motivation of the Project of Bill on Judicial Control of Public Policies. in $O$ controle Jurisdicional de Políticas Públicas, coord. Ada Pellegrini Grinover e Kazuo Watanabe, Gen-Forense, 2a ed, 2013, Apêndice. 